\title{
JAVANESE LANGUAGE OF BANTEN DIALECTS IN TANGERANG REGENCY
}

\author{
Agus Sulaeman, M.Pd. \\ Lecturer of Muhammadiyah-University of Tangerang \\ Sultanwahyu13@gmail.com
}

\begin{abstract}
ABSTRACK
The purpose of this study was to determine the phonological and morphological structure of the Java language dialect of Banten. The method used is descriptive-research. The researcher used methods into the field directly with data collection done by recording the written language and spoken language recording data. The study was conducted in the District Kronjo and Mekar Baru subdistrict, Tangerang. Both districts are predominantly speak dialects of Java Banten. The data described are living languages and used in Tangerang. The data is sourced from the spoken language. The sample is done randomly based on the use of languages in order to obtain sorts of the Java language dialect Banten. Informants were used as sources of information and data. This informants used in this study are (1) native speakers who settled in the area, (2) are not physically disabled, especially those associated with the pronunciation, and (3) have a good memory. For the validity of the data is taken at least two informants in every village. In addition to the informant, the informants also who have sufficient knowledge in the field of the realm of life to get certain vocabulary typical area of Tangerang, so as to know the structure of the phonology and morphology of the Java language dialect Banten.
\end{abstract}

Key Word. Javanese language dialect Banten

\section{A. INTRODUCTION}

\section{Background}

Up to this present, the Java language, including the dialects, still exist in the community. Javanese dialect Tangerang Regency is a dialect of Javanese dialects which are still exist on the area of north coast of Banten. According to 
the observations of researchers, until now no one has conducted research on Javanese dialect phonological Tangerang Regency. Therefore, the study of the Javanese dialect phonological Tangerang Regency.

Every single person in daily life using the language. Language is a means of communication. Humans use language as a communication tool to connect, share experiences submission of ideas and concepts. Language used by humans in all activities of life. Thus, the language is most essential in human life.

Bahasa Indonesia is used in many areas of Indonesia, and a profusion of native speakers, inevitably, subject to the laws change. Direction of change is not always inevitable because we can also change the language in a planned way. The factor of history and development of the community also help to influence the emergence of a variety of Indonesian. Characteristics and norms of sound, word formation, and meaning are generally similar. That is why we are still able to understand people who speak Indonesian, although it is still recognizable some differences in the Indonesian language. This occurs because of the influence of the local language.

Variety of region has been known by the name of accent or dialect. Language which widespread always has familiar accent. Each of these can be understood by speakers on a reciprocal basis, at least by the regional dialect speakers who are located side by side. If within the wearer people do not easily relate, for example, because his residence is separated by mountains, straits or sea, then gradually accent in progress will be changed so that ultimately it is considered a different language.

\section{The Objective}

The objective of this research is to determine the phonological and morphological structure of the Java language dialect of Banten

\section{Theoretical Framework}

3.1 Dialek and idiolect 
Dialect is something autonomous therefore dialect has its own linguistic system. Mahsun (2010: 54) says in discussion about the introduction of dialect then presented linguisitk are characteristics that distinguish between dialects with other dialects. The linguistic characteristics may involve phonological or morphological characteristics depending on the presence or other characteristics that distinguish linguistic dialect with other dialects in the researched language. Meanwhile Moleono (1988: 159) in Sobarna and Tini (2004: 30) equate the term of dialect and accent. Their opinions that Bahasa Indonesia with a vast area of its range and a wide assortment of native speakers can not be affected by the law of change. However, it can not be denied since the first Indonesian has a variety of languages.

In addition to the dialect, there is another kind of language variation. According Chaer and Agustina (2004: 62) The first language variations we see by their speakers are variations of a language called idiolect, they are individual variations. According to the concept of each idiolect, this idiolec variation respective relates to "color" the sound of it, so if we are quite familiar with someone just to hear his/her voice we can recognize him/her. To know someone's idiolect, just to hear his voice we can recognize it. recognizing a person's Idiolect is easier from the speech rather than through the work of writing. The second variation of language, namely, called dialect, the language variations from comparatively speaking group, which is in one place, a particular region or area.

The third language variation according Chaer and Agustina (2004: 64) says that dialects are divided into: temporal dialect, and kronolek, the variation of the language used by the social group at a particular time. Example, Indonesian variations during the thirties and today's Indonesian variations will be different. Still according Chaer and Agustina (2004: 64), they said that Sociolect or social dialect, is a variation of the language relating to the status, class, and social class of the audienct. It means from the above opinion, that regional dialects are still used by people around because they still have vitality of language, so that, those areas still retains the language and culture. 
Especially the areas along the coast ranging from Ujung Kulon to Tangerang, West and North, particularly in the area of Tangerang, Banten.

\subsection{Javanese dialect Banten}

Phase of the spread of Islam in Banten in the XVI century when it was under the control of the power of Java (1521-1619). This critical period can be divided into two sub-phases, that is before and after 1596, when the Dutch came shortly after Britain. This phase showed the conquest of old Banten and then the Capital of Pajajaran by forces in Central Java led by Sunan Gunung Jati and Maulana Hasanuddin. In line with the arrival of Fatahillah and his followers from Demak, since then the language and culture of Islam Demak Banten region also used, especially areas along the northern coast. Banten communities along the northern coast (most of Serang and Tangerang regency northern coast and the western part) that previously used Sundanese language and culture began to recognize and accept the Javanese language and culture of the Sultanate of Demak and Cirebon. The possibility since this event, the term of the Javanese language (dialect) Kronjo Banten on its development happened to associate with the Sundanese language so become the Java language (dialect) Kronjo Banten. The spread of the Javanese language with the Islamic students and Islamic priest (called Kyai). Since that time, the spread was largely focused along the coast and the area of river streams, such as Cisadane rivers, and Cidurian river passing through the district of Tangerang, because at the time, the transportation used more was using water transport. Spreading of Islamic religion, the language used was the the Javanese language, it created acculturation of Javanese language with the languages of indigenous peoples.

\section{Methodology}

The research used in this study is field research because the researchers went directly to the public with data collection done by recording done on the written language data, such as the utilization of the results of previous research and related to languages in Tangerang. Recording was done 
to obtain the spoken language data. Implementation of this technique was done through direct conversations between the researchers and informants.

\section{B. RESULT AND DISCUSSION}

\section{Structure}

Javanese language dialect of Banten Tangerang District structurally is not much different from the standard Javanese language. Historically the Javanese language in Tangerang regency is not apart from existance of the Javanese language dialect Banten, because Banten Sultanate's territory covers an area of Tangerang today.

In the pronunciation of the phoneme / a / the final position of the Java language in the district pronounce with (a). This differs from the pronunciation in Serang Javanese language, for example, the word sira 'you' in Javanese Tangerang Regency remains pronunced ( $\mathrm{s}$ i $\mathrm{r}_{\text {ə) }}$ ).

Another difference, the dialect of Banten in Tangerang district is about the following cases.

Calculation vowel / $\mathrm{i} /$ at the initial position.
1. $i k u \rightarrow k u$
'that'
2. $i k i \rightarrow k i$
'this'

Calculation consonant / $\mathrm{n} /$ and / eng / at the initial position:

1. njare $\rightarrow$ Jare 'his saying'

2. enggone $\rightarrow$ gone 'worn'

Disappearance consonant / $\mathrm{h} /$ at the final position:
1. umah $\rightarrow$ uma
'house'
2. warah $\rightarrow$ wara
'teaching'

In addition, Sundanese Tangerang District does not recognize phonemes /dh/ and /th/. Thus the words:
1. adhep $\rightarrow$ adep
'face'
2. sathitik $\rightarrow$ satitik 'little' 
In the field of morphology generally is the same, but associated with Malay, Javanese dialect of Banten Tangerang regency also found the influence of the Malay language in the form of basic vocabulary of Malay gets the Javanese affixes, such as biasane 'normally' and sehari-hari 'daily'. In Javanese dialect Banten Tangerang District also found affixes (prefixes) in the form of:

Prefix:
me-
e.g., me- + gawe $\rightarrow$ megawe
'work'
di-
e.g., di- + weruh $\rightarrow$ diweruh
'notified'

suffix:
$-e$
e.g., lawang $+e \rightarrow$ lawange
'door'
-ne
e.g., $\quad k a y a k+n e \rightarrow$ kayakne
'seems'

The formation of words through reduplication also found in Javanese dialect Banten in Tangerang district, such as:

Two basic words: buru 'quick' $\rightarrow$ buru-buru $\quad$ 'quickly'

$$
\text { Bengi 'night' } \rightarrow \text { bengi-bengi 'late night' }
$$

Two basic words affixed: itung 'count' $\rightarrow$ itung-itungan 'calculation'

$$
\text { pesta 'party' } \rightarrow \text { pesta-pestaan 'partying' }
$$

\section{Vocabulary}

In the field of vocabulary, Javanese dialect Banten Tangerang District, absorbing the Sundanese language vocabulary, especially of such particles ' $m a h$ ' and 'oge'. In addition, also found special vocabulary of Javanese dialect of Banten, Tangerang regency as jagir 'calves' pusing 'dizzy', and sedelat 'a moment', as well as in terms of greeting, for boys 'seding' and for girls 'senong'. The words are not found in the standard of Javanese language.

\section{CONCLUSION}

This research can be seen as an effort to strengthen and complete the previous research results. Based on this study, can be concluded that:

1. The structure of the languages that exist in Tangerang Regency is similar as the standard of every language. (Sound system), especially about the intonation. 
2. Another striking difference with regard to vocabulary is that vocabulary is at once to be the distinguishing characteristics (dialect) languages that exist in the district of Tangerang.

\section{BIBLIOGRAPHY}

Alwasilah, Chaedar. Linguistik Suatu Pengantar. Bandung: Angkasa, 2010.

Arikunto, Suharsimi. Prosedur Penelitian Suatu Pendekatan Praktik.

Jakarta : Rineka Cipta, 2006.

Brown, H. Douglas. Prinsip Pembelajaran dan Pengajaran Bahasa.

Kedubes AS: Pearson Education Inc., 2007.

Chaer, Abdul. Pengantar Semantik Bahasa Indonesia. Jakarta: Rineka

Cipta, 2009.

------------- Morfologi Bahasa Indonesia. Jakarta: Rineka Cipta, 2008.

------------- Linguistik Umum. Jakarta : Rineka Cipta, 2007. dan Leonie Agustina. Sosiolinguistik Perkenalan Awal.

Jakarta: Rineka Cipta, 2004.

Doan, Thi Tuyen.2012. the Prospect For Language Diversity in Vietnam.

Vitnam: Institut For Cultural Studies.

Dardjowidjojo, Soenjono. Psikolinguistik Pengantar Pemahaman

Bahasa Kedua. Jakarta: Yayasan Obor Indonesia, 2008.

Ekadjati, Edi.S. dan Hardjasaputra. Sejarah Kabupaten Tangerang.

Tangerang: PEMKAB TANGERANG, 2004.

Hasan, Alwi. Tata Bahasa Baku Bahasa Indonesia.Jakarta. Balai

Pustaka, 2010

Hakim, Lukman. Banten Dalam Perjalanan Jurnalistik. Pandeglang:

Banten Heritage, 2006.

Kusnandar, Mas Iman. Rekam Jejak H. Ismet Iskandar Sepuluh Tahun

Memimpin Kabupaten Tangerang. Jakarta: Tiara Media Pustaka, 2012. 
Kosaih,E. Kompetensi Ketatabahasaan dan kesusatraan. Bandung:

Yrama Widya, 2003.

Mahsum. Genolinguistik Kolaborasi Linguistik Dengan Genetika Dalam

Pengelompokan Bahasa dan Populasi Penuturnya. Yogyakarta:

Pustaka Pelajar, 2010.

Mar'at, Samsunuwiyati. Psikolinguistik Suatu Pengantar.Bandung:

Refika Aditama, 2011.

Muflihah. Interferensi Bahasa Jawa Dialek Banten dalam Karangan

Narasi Siswa kelas IV di Sekolah Dasar Walikukun Cilegon.

UNTIRTA: Tesis, 2011.

Moleong. Lexy J. Metodologi Penelitian Kualitatif. Bandung: Remaja

Rosdakarya, 2005.

Nurhadi, Roekhan. Dimensi-dimensi Dalam Belajar Bahasa Kedua.

Bandung: Sinar Baru, 2006.

Premsirirat,Suwilay. Mahidol Model For ThePreservationof Language

diversity. Thailand: Mahidol university, 2012.

Rukmana, Endang. Banten Bangkit Saatnya Otak Bukan Otot. Serang:

Gong Publishing, 2010.

Ramlan. Morfologi Suatu Tinjauan Deskriptif. Yogyakarta: CV Karyono, 2009.

Sugiyono. Memahami Penelitian Kualitatif. Bandung Alfabeta, 2009.

Suyatno. Teknik Pembelajaran Bahasa dan Sastra. Surabaya: SIC, 2010.

Sobarna, C. dan Wartini. Bahasa dan Sastra Daerah di Kabupaten

Tangerang. Bandung: Pemkab Tangerang, 2004.

Verhaar, J.W.M. Asas-Asas Linguistik Umum.Yogyakarta: UGM Press, 2010. 